\title{
Effectiveness of the Botulinum Toxin for Treating Sialorrhea in Patients with Parkinson's Disease: A Systematic Review
}

\author{
Juan Antonio Ruiz-Roca ${ }^{1}$, Eduardo Pons-Fuster ${ }^{2}$ and Pia Lopez-Jornet ${ }^{3, *(1)}$ \\ 1 Department of Stomatology, Faculty of Dentistry, University of Murcia, 30008 Murcia, Spain; \\ jaruizroca@um.es \\ 2 Research Investigations, Instituto Murciano de Investigación Biosanitaria (IMIB), 30120 Murcia, Spain; \\ eduardo.p.f@um.es \\ 3 Oral Medicine in the Department of Stomatology, Faculty of Dentistry, University of Murcia, \\ 30008 Murcia, Spain \\ * Correspondence: majornet@um.es; Tel.: +34-968-398588
}

Received: 2 February 2019; Accepted: 4 March 2019; Published: 6 March 2019

check for updates

\begin{abstract}
The main objective was to assess the efficacy of botulinum toxin-based treatment for sialorrhea in adult patients with Parkinson's disease. The search was performed by using the Medline-PubMed, EMBASE and Cochrane Library databases from January 2000-December 2017, in English/Spanish in patients with Parkinson's disease and sialorrhea. The methodological quality of trials was carried out by following the PRISMA (Preferred Reporting Items for Systematic Reviews and Meta-Analyses) criteria and the Newcastle-Ottawa Scale (NOS). Finally, a total of 21 articles were identified as fulfilling the inclusion criteria. There is no consensus regarding the site of injection of the toxin (single or multiple points), toxin dose or follow-up period. In all cases there was a reduction of sialorrhea. Treatment safety increases with the use of ultrasonography. Effects approximately occur at one week post-injection and for 3-5 months. Botulinum toxin is an effective therapeutic strategy or option in treating sialorrhea in adult patients with Parkinson's disease. More studies with a better design, larger samples and a longer follow-up period are required to confirm these data.
\end{abstract}

Keywords: botulinum toxin; sialorrhea; drooling; Parkinson's disease

\section{Introduction}

Parkinson's disease is a chronic and progressive neurodegenerative condition with such an incidence [1] that, as the condition progresses, patients experience a deterioration of motor and non-motor symptoms [2]. The prevalence of sialorrhea in PD patients ranges from 10\% to 86\% [3-7].

Sialorrhea can lead to social and functional deficiencies, including shame and social isolation, oral and skin fungal infections, deglutition pneumonia, skin maceration, halitosis, and dehydration [2,8]. The treatment of sialorrhea in these patients aims at reducing drooling with a good risk-benefit ratio [9-12]. Treatments such as myofascial therapy and anticholinergic drugs-which inhibit the production of saliva-have a wide variety of side effects. Cheng et al. [10] find that dihydroergotoxine mesylate ( $\alpha$-adrenergic blocking agents) may attenuate sialorrhea in PD, showing minor adverse effects. In addition, invasive treatments such as surgery or radiotherapy are currently being offered for controlling sialorrhea $[4,5,8,9]$. 
An alternative or adjuvant treatment would be botulinum toxin, BoNT, which comprises proteases (seven serotypes, from $\mathrm{A}-\mathrm{G}$ ), and is produced by Clostridium botulinum bacteria. Such bacteria are capable of stopping the release of acetylcholine from the presynaptic nerve terminals of the neuromuscular junction, of blocking muscle contraction and the activity of the glands in the postganglionic synapses-orthosympathetic, parasympathetic. Botulinum toxin has become an important therapeutic option in the field of movement disorders, especially for focal and generalised dystonia. BoNT type A (BoNT-A) and type B (BoNT-B) are commonly used for therapeutically managing dystonia and spasticity [2-11].

Botulinum toxin injected into the parotid gland was proposed by Bushar in 1997 for treating sialorrhea. Several studies [3,6,7,12-14] showed strong evidence that serotypes A and B are very effective, with few side effects in various diseases, primarily in ALS (Amyotrophic Lateral Sclerosis) and PD (Parkinson's disease).

Botulinum toxin blocks the presynaptic release of acetylcholine in parasympathetic ganglia. The effect is temporary and lasts until the presynaptic terminals regenerate, usually up to three months [15]. Accordingly, repeated injections are required [16]. Despite the importance of the application of botulinum toxin to treat sialorrhea in Parkinson's disease, there is lack of clear consensus concerning the safest and most effective treatment method and specific clinical guidelines or recommendations.

The objective of this paper is to conduct a systematic review by analysing published clinical studies regarding the efficacy of the treatment of sialorrhea with botulinum toxin injections in patients with Parkinson's disease.

\section{Materials and Methods}

The literature search strategy, the methods for this systematic review, as well as the study design, were determined by the authors with a protocol prior to the review process.

\subsection{Focused Methodology}

The search strategy was performed with populations, exposures and outcomes (PEO) in order to synthesise the following question: Is the botulinum toxin therapy effective for treating sialorrhea in patients with Parkinson's disease (Table 1)?

Table 1. Population, exposure and outcomes (PEO).

\begin{tabular}{cc}
\hline Focused Question & $\begin{array}{c}\text { Is the Botulinum Toxin Therapy Effective for Treating Sialorrhea in } \\
\text { Patients with Parkinson's Disease? }\end{array}$ \\
\hline $\begin{array}{c}\text { Population } \\
\text { Exposure }\end{array}$ & $\begin{array}{c}\text { Patients with Parkinson's disease and sialorrhea } \\
\text { Patient under treatment with botulinum toxin }\end{array}$ \\
Outcomes & $\begin{array}{c}\text { Administered doses, treatment outcomes, side effects, efficacy of } \\
\text { treatment over time }\end{array}$ \\
\hline
\end{tabular}

\subsection{Search Strategy}

Two reviewers (JARR and PLJ) independently conducted an exhaustive search of four databases: Medline-PubMed, EMBASE and Cochrane Library, following PRISMA (Preferred Reporting Items for Systematic Reviews and Meta-analyses) 2009 statements (http://www.prismastatement.org) throughout the selection process. They used a combination of keywords ("Botulinum toxin and Sialorrhea" and "Botulinum toxin and Drooling") in "Parkinson's disease". Articles were limited to those published between January 2010 and December 2017, and whose studies were performed only in human beings. In the first round only titles and abstracts of retrieved articles were analysed. Then in a second round all considered eligible studies were fully examined and final decisions about inclusions were made. In case of disagreement a third reviewer (EPF) participated in order to reach consensus. 


\subsection{Selection Criteria}

Clinical trials in patients over 18 years of age diagnosed with PD and sialorrhea who had been treated with intraglandular botulinum toxin to treat sialorrhea were included [1]. If the sample of the study included several neurological conditions, only PD patients were included in this study. Studies were excluded when (1) sample less than eight patients, (2) those that were published in a language different from English or Spanish, (3) meta-analysis, literature reviews, posters or communications and letters to the editor, and (4) application of botulinum toxin for indications other than sialorrhea. Efficacy, safety and doses used were collected.

\subsection{Outcome Measurement Type}

Studies assessing the effectiveness of the therapy were included in our review. They assessed such efficacy by using quality of life questionnaires, Clinical Global Impression scale, Drooling Frequency and Severity Scale, unstimulated salivary flow rate and VAS (Visual Analogic Scale).

The information extracted from each of the papers included associated pathology, sample size, study design, intervention, outcome measures, duration of follow-up process, outcomes, and side effects. Papers were classified in accordance with their level of scientific evidence by following the Newcastle-Ottawa Scale (NOS) criteria (score ranges between zero up to nine points, representing the lowest and the highest quality)

\section{Outcomes}

Of the 191 studies initially obtained after the keyword search, 170 were rejected for not fulfilling the inclusion criteria, so the full text of 21 documents was finally analysed (Figure 1). A fundamental inclusion criterion was that patients with sialorrhea were diagnosed with Parkinson's disease, eight of the 21 studies analysed samples that included patients with PD and other neurodegenerative conditions, such as ALS, cerebral palsy, or encephalitis. PD comprised between $20 \%$ and $73 \%$ of the total sample. With regard to the sample size, this was variable. In only seven studies more than 30 patients with PD participated, and in one of these studies, the largest, 117 out of 160 participants suffered from this disease [2].

The total number of participants was 641 . The age of the patients under study was over 53, with a mean between 68 and 70 years approximately.

Among all the salivary glands, the parotid gland is the major target when injecting botulinum toxin in all studies, and can be treated alone $[6,7,16]$ or, what happens in most studies $[3,10,14,15,17,18]$, along with the submandibular glands, since both produce $90 \%$ of total saliva. There are two studies $[4,19]$ that do not specify into which gland the treatment is applied. Nevertheless, there is no consensus regarding the site of injection in the parotid gland, since some authors inject botulinum toxin in a single point, whereas others distribute the same dose in two or three different points into the same gland.

With regard to the technique for guiding the injection needle, the submandibular case is performed through palpation, and to locate the injection point in the parotid gland most studies are guided by ultrasound or ultrasonography at a frequency between 7.5 and $12 \mathrm{MHz}$, Although other authors advocate palpation and externally marking on the skin, a series of anatomical landmarks as guidance or reference points. In one study the method of guiding the injection needle is not specified [18] and in another one electromyography is utilised [2] (Table 2). 
Table 2. Characteristics of Included Studies.

\begin{tabular}{|c|c|c|c|c|c|c|}
\hline Author & $\begin{array}{l}\text { Number of } \\
\text { Patients }\end{array}$ & Study Design & Outcome Measurement & Findings & $\begin{array}{l}\text { Method to Locate } \\
\text { Glands }\end{array}$ & Side Effects \\
\hline Lagalla et al. [20] & 36 & $\begin{array}{l}\text { A double-blind, } \\
\text { randomised, } \\
\text { placebo-controlled } \\
\text { study }\end{array}$ & $\begin{array}{l}\text { Drooling Severity and Frequency Scale, } \\
\text { DSFS, visuo-analogic ratings of familial } \\
\text { distress, VAS-FD, and social distress, } \\
\text { VAS-SD) and (saliva production by } \\
\text { weighing dental rolls. The Global } \\
\text { Impression Score (GIS) }\end{array}$ & $\begin{array}{l}\text { BTXB represents a safe and efficacious } \\
\text { tool for the management of PD related } \\
\text { drooling, ensuring a long-lasting } \\
\text { waning of this disabling symptom. }\end{array}$ & $\begin{array}{l}\text { External anatomical } \\
\text { landmarks }\end{array}$ & $\mathrm{x}$ \\
\hline Tiigimäe-Saa et al. [21] & 20 & open clinical trial & $\begin{array}{l}\text { Drooling was evaluated using subjective } \\
\text { scales and objective assessment of salivary } \\
\text { flow rate and oral health. }\end{array}$ & $\begin{array}{l}\text { BNT-A injections according to the } \\
\text { current protocol can effectively manage } \\
\text { sialorrhea while maintaining oral health. }\end{array}$ & Ultrasound guidance & $\mathrm{x}$ \\
\hline Svetelet al. [22]. & 13 & open clinical trial & $\begin{array}{l}\text { Activities of Daily Living of the Unified } \\
\text { Parkinson's Disease Rating Scale (UPDRS). }\end{array}$ & $\begin{array}{l}\text { Botulinum toxin-A injections to easily } \\
\text { accessible parotid glands, without } \\
\text { necessity for ultrasound guidance. }\end{array}$ & $\begin{array}{l}\text { Ultrasound guidance } \\
\text { and External } \\
\text { anatomical } \\
\text { landmarks }\end{array}$ & $\mathrm{x}$ \\
\hline Lagalla et al. [23] & 32 & $\begin{array}{l}\text { double-blind, } \\
\text { randomized } \\
\text { placebo-controlled } \\
\text { study }\end{array}$ & $\begin{array}{l}\text { Subjective measures included a visual } \\
\text { analogue rating of drooling frequency } \\
\text { (VAS-D), as well as assessment of patient } \\
\text { embarrassment within the familial (VAS-FD) } \\
\text { and social (VAS-SD) context. }\end{array}$ & $\begin{array}{l}\text { Subjects treated with BoNTX } \\
\text { experienced a reduction in both drooling } \\
\text { frequency and familial and social } \\
\text { disability (Time } \times \text { Group effect: } \\
p<0.01 \text { ), as well as in saliva production } \\
\text { (Time } \times \text { Group effect: } p<0.0001 \text { ). }\end{array}$ & $\begin{array}{l}\text { External anatomical } \\
\text { landmarks }\end{array}$ & $\mathrm{x}$ \\
\hline Nóbrega et al. [24] & 21 & open clinical trial & Drooling severity and frequency & $\begin{array}{l}\text { The severity of drooling decreased in } 18 \\
(86 \%) \text { patients, while frequency was } \\
\text { reduced in } 8(38 \%) \text {. In } 11(52 \%) \text { patients, } \\
\text { the frequency of drooling remained } \\
\text { constant. }\end{array}$ & Ultrasound & bilateral local oedema \\
\hline Ondo, W.G. [25] & 16 & $\begin{array}{l}\text { A double-blind } \\
\text { placebo/treatment }\end{array}$ & $\begin{array}{l}\text { The Unified Parkinson's Disease Rating } \\
\text { Scale (UPDRS), questionnaires regarding } \\
\text { drooling, Visual Analogue Scale, global } \\
\text { impressions, salivary gland imaging, and a } \\
\text { dysphagia questionnaire. }\end{array}$ & $\begin{array}{l}\text { Injections of botulinum toxin B into the } \\
\text { parotid and submandibular glands } \\
\text { appear to effectively improve sialorrhea } \\
\text { without compromising dysphagia in } \\
\text { patients with PD. }\end{array}$ & Anatomic landmarks & $\mathrm{x}$ \\
\hline Mancini, F. [26] & 20 & $\begin{array}{l}\text { Double-blind, } \\
\text { placebo-controlled } \\
\text { study }\end{array}$ & $\begin{array}{l}\text { Drooling Severity and Drooling Frequency } \\
\text { scales }\end{array}$ & $\begin{array}{l}\text { BTX injection into parotids and } \\
\text { submandibular glands, is an effective } \\
\text { and safe treatment for drooling. }\end{array}$ & Ultrasound & $\mathrm{x}$ \\
\hline Friedman et al. [27] & 11 & Cases/control & $\begin{array}{l}\text { The Unified Parkinson's Disease Rating } \\
\text { Scale (UPDRS), saliva production by } \\
\text { weighing dental rolls. }\end{array}$ & $\begin{array}{l}\text { Botulinum toxin may be an effective and } \\
\text { safe treatment of parkinsonian } \\
\text { sialorrhea. }\end{array}$ & Anatomic landmarks & No \\
\hline
\end{tabular}


Table 2. Cont.

\begin{tabular}{|c|c|c|c|c|c|c|}
\hline Author & $\begin{array}{l}\text { Number of } \\
\text { Patients }\end{array}$ & Study Design & Outcome Measurement & Findings & $\begin{array}{l}\text { Method to Locate } \\
\text { Glands }\end{array}$ & Side Effects \\
\hline Pal et al. [28] & 9 & open clinical trial & $\begin{array}{l}\text { Rating scales for severity and frequency of } \\
\text { drooling and saliva production by weighing } \\
\text { dental rolls. }\end{array}$ & $\begin{array}{l}\text { Intraparotid BTX-A can be a useful, safe, } \\
\text { and simple treatment for reducing the } \\
\text { accumulation of saliva in neurologically } \\
\text { impaired patients. }\end{array}$ & Anatomic landmarks & No \\
\hline Santamato et al. [29] & 18 & open clinical trial & $\begin{array}{l}\text { Questionnaire-Based Scoring System for } \\
\text { Drool-the dose of Botox used per parotid } \\
\text { glanding Severity and Frequency. }\end{array}$ & $\begin{array}{l}\text { The severity and the frequency of } \\
\text { drooling decreased in all patients after } \\
\text { BTX-A after a 30-day follow-up. }\end{array}$ & Ultrasound & $\begin{array}{l}\text { adverse effects could be } \\
\text { dysphagia and chewing } \\
\text { difficulties }\end{array}$ \\
\hline Breheret et al. [17] & 14 & $\begin{array}{l}\text { Retrospective review } \\
\text { between May } 2002 \\
\text { and February } 2008\end{array}$ & $\begin{array}{l}\text { Quality of life questionnaire from } 6-8 \text { weeks } \\
\text { after the injections. }(0=\text { no efficacy, } \\
1=\text { partial efficacy, } 2=\text { good efficacy but of } \\
\text { brief duration }(<1 \text { month), } 3=\text { very effective: } \\
\text { resolution of drooling, } 4=\text { patient died or } \\
\text { lost to follow-up). }\end{array}$ & $\begin{array}{l}\text { Beneficial effect in } 66 \% \text { of cases. The } \\
\text { most effective protocol was injection of } \\
20 \mathrm{U} \text { of toxin into each submandibular } \\
\text { (submaxillary) gland and } 30 \mathrm{U} \text { into each } \\
\text { parotid gland. }\end{array}$ & Ultrasound & $\begin{array}{l}\text { No major complications } \\
\text { were observed } \\
\text { (haematoma of the floor } \\
\text { of the mouth or } \\
\text { paralysis). }\end{array}$ \\
\hline Bruno et al. [4] & 160 & $\begin{array}{l}\text { Retrospective review } \\
\text { of patients who } \\
\text { received treatment } \\
\text { with injections } \\
\text { between } 1995 \text { and } \\
2014\end{array}$ & $\begin{array}{l}\text { Response to treatment was assessed by } \\
\text { using a subjective Clinical Global } \\
\text { Impression (CGI) consisting of five points } \\
(3=\text { very much improved, } \\
2=\text { much improved, } \\
1=\text { minimally improved, } 0=\text { no change, } \\
\text { and }-1=\text { worse). The CGI assessment was } \\
\text { performed after the first set of injections and } \\
\text { in the last recorded visit. }\end{array}$ & $\begin{array}{l}\text { Improvement in pain in } 81 \% \text { of cases, } \\
\text { which was maintained in the last } \\
\text { recorded visit, without significant } \\
\text { differences with the result after the first } \\
\text { injection. BTX treatment could play a } \\
\text { safe and useful role in the treatment of } \\
\text { pain in this population. }\end{array}$ & Electromyography & $\mathrm{x}$ \\
\hline Chinnapongse et al. [6] & 54 & $\begin{array}{l}\text { Prospective, } \\
\text { multicentre, } \\
\text { randomised, } \\
\text { double-blind design }\end{array}$ & $\begin{array}{l}\text { Follow-up of subjects for four weeks and up } \\
\text { to } 20 \text { weeks. Primary measure: } \\
\text { safety/tolerability as assessed by adverse } \\
\text { events. Secondary measure: Efficacy, } \\
\text { assessed by means of the Drooling } \\
\text { Frequency and Severity Scale and } \\
\text { unstimulated salivary flow rate. }\end{array}$ & $\begin{array}{l}\text { Gastrointestinal adverse events in } 31 \% \\
\text { of the active group compared to } 7 \% \text { in } \\
\text { the placebo group, with dry mouth } \\
\text { being the most common. No serious } \\
\text { adverse events or treatment } \\
\text { discontinuations due to adverse events. } \\
\text { Significant improvement in DFSS at } \\
4 \text { weeks postinjection and decreased } \\
\text { unstimulated salivary flow rate. }\end{array}$ & $\begin{array}{l}\text { External anatomical } \\
\text { landmarks }\end{array}$ & $\mathrm{x}$ \\
\hline Gómez-Caravaca et al. [7] & 53 & $\begin{array}{l}\text { Retrospective study } \\
\text { with a long-term } \\
\text { follow-up, between } \\
2007 \text { and } 2013 \text {. }\end{array}$ & $\begin{array}{l}\text { Variables: previous treatment, number of } \\
\text { visits, average dose administered, duration } \\
\text { of treatment effect and latency, assessment } \\
\text { of response to treatment (less drooling), } \\
\text { increased doses, mean years of follow-up } \\
\text { and adverse events. The response to } \\
\text { treatment was evaluated on a scale of } 1 \\
\text { (minimal response) to } 10 \text { (maximum } \\
\text { response), and patients were considered as } \\
\text { responders if they scored greater than zero } \\
\text { in this scale. }\end{array}$ & $\begin{array}{l}\text { There was an improvement after } \\
\text { treatment in } 65.22 \% \text { of patients with an } \\
\text { average score of } 6.85 \pm 1.58 \text { points on a } \\
\text { scale from } 0 \text { to } 10 \text {. The duration of the } \\
\text { effect of treatment was } 4.38 \pm 2.11 \\
\text { months, with a latency period of } \\
10.06 \pm 9.63 \text { days. }\end{array}$ & $\begin{array}{l}\text { External anatomical } \\
\text { landmarks }\end{array}$ & $\begin{array}{l}\text { Mild and infrequent: } \\
\text { skin reaction and } \\
\text { weakness in the } \\
\text { muscles of mastication } \\
\text { and one case of } \\
\text { previous dysphagia } \\
\text { was slightly } \\
\text { exacerbated. }\end{array}$ \\
\hline
\end{tabular}


Table 2. Cont.

\begin{tabular}{|c|c|c|c|c|c|c|}
\hline Author & $\begin{array}{l}\text { Number of } \\
\text { Patients }\end{array}$ & Study Design & Outcome Measurement & Findings & $\begin{array}{l}\text { Method to Locate } \\
\text { Glands }\end{array}$ & Side Effects \\
\hline Mazlan et al. [11] & 30 & $\begin{array}{l}\text { Prospective, } \\
\text { double-blind } \\
\text { randomised } \\
\text { controlled trial } \\
\text { between September } \\
2010 \text { and February } \\
2014\end{array}$ & $\begin{array}{l}\text { The primary outcome was the amount of } \\
\text { saliva reduction, measured by the } \\
\text { differential weight (wet versus dry) of } \\
\text { intraoral dental gauze at baseline and at 2, 6, } \\
12 \text { and } 24 \text { weeks after injection. The } \\
\text { secondary outcome was the subjective } \\
\text { report of drooling by using the Drooling } \\
\text { Frequency and Severity Scale (DFSS). }\end{array}$ & $\begin{array}{l}\text { Saliva reduction in response to all doses } \\
\text { of botulinum toxin A. No significant } \\
\text { differences between doses. Greater } \\
\text { mean reduction in those groups } \\
\text { receiving the highest doses. The group } \\
\text { that received } 200 \text { U of Dysport @showed } \\
\text { the greatest saliva reduction until } \\
24 \text { weeks and reported the most } \\
\text { significant improvement in the } \\
\text { DFSS score. }\end{array}$ & Ultrasound & Viscous saliva \\
\hline Guidubaldi et al. [14] & 14 & $\begin{array}{l}\text { Prospective, } \\
\text { randomised, } \\
\text { double-blind, } \\
\text { crossover pilot study }\end{array}$ & $\begin{array}{l}\text { Objective evaluations (cotton roll weight) } \\
\text { and subjective evaluations (ad hoc clinical } \\
\text { scales) were performed at baseline, after one } \\
\text { and four weeks, and every four weeks until } \\
\text { drooling returned to baseline. }\end{array}$ & $\begin{array}{l}\text { Subjective and objective improvements } \\
\text { in all patients. Latency was shorter upon } \\
\text { use of botulinum toxin B (three days) } \\
\text { compared to botulinum toxin A (six } \\
\text { days). The mean duration of benefits } \\
\text { was similar for bot. toxin A ( } 75 \text { days) } \\
\text { and B ( } 90 \text { days). Either } 250 \text { U Dysport or } \\
2500 \text { U Neurobloc have similar } \\
\text { effectiveness and safety in controlling } \\
\text { sialorrhoea. }\end{array}$ & Ultrasound & $\begin{array}{l}\text { Change to saliva } \\
\text { thickness }\end{array}$ \\
\hline Møller et al. [3] & 12 & $\begin{array}{l}\text { Open, prospective } \\
\text { study }\end{array}$ & $\begin{array}{l}\text { Patients were followed up for two months } \\
\text { with evaluations every second week by } \\
\text { means of self-assessed rating scales for } \\
\text { drooling intensity, discomfort and treatment } \\
\text { effect, and determination of unstimulated } \\
\text { whole saliva flow rate. }\end{array}$ & $\begin{array}{l}\text { Drooling and saliva flow were reduced } \\
(p<0.05) \text { two weeks after treatment, } \\
\text { without side effects. The maximal } \\
\text { reductions during the observation } \\
\text { period were } 40 \% \text { for drooling and } 30 \% \\
\text { for saliva flow. There was a variation in } \\
\text { flow. Amylase activity and total protein } \\
\text { concentration generally increased with } \\
\text { decreasing flow }(p \leq 0.03) \text {. }\end{array}$ & Ultrasound & $\begin{array}{l}\text { Seven patients dropped } \\
\text { out shortly after the } \\
\text { first treatment due to } \\
\text { marked worsening of } \\
\text { their disease-related } \\
\text { condition. }\end{array}$ \\
\hline Møller et al. [15] & 17 & & $\begin{array}{l}\text { Discomfort caused by drooling was rated on } \\
\text { a VAS }(0-100) \text {, and on a scale describing } \\
\text { frequency and severity of drooling } \\
(0=\text { no drooling/dry to } \\
7=\text { constant drooling). Measures were } \\
\text { obtained after } 6,12 \text { and } 18 \text { weeks. } \\
\text { Perception of treatment effectiveness was } \\
\text { also measured. Saliva flow was measured } \\
\text { with cotton rolls in 2-min collection periods. } \\
\text { The composition of saliva was also } \\
\text { analysed. }\end{array}$ & $\begin{array}{l}\text { Number of treatment series in each } \\
\text { patient was } 1-7 \text {. Saliva flow rate and } \\
\text { drooling were reduced } 30 \%-70 \% \text { six } \\
\text { weeks after treatment in the first series, } \\
\text { while sodium, chloride, and total } \\
\text { protein increased } 20-80 \% \text { ( } t \text {-tests; } \\
p<0.05) \text {. After } 12 \text { weeks, drooling was } \\
\text { still significantly reduced }(20 \%) \text {, saliva } \\
\text { flow tended to be, and saliva } \\
\text { composition was back to baseline. }\end{array}$ & Ultrasound & $\begin{array}{l}\text { Viscous saliva and dry } \\
\text { mouth }\end{array}$ \\
\hline
\end{tabular}


Table 2. Cont.

\begin{tabular}{|c|c|c|c|c|c|c|}
\hline Author & $\begin{array}{l}\text { Number of } \\
\text { Patients }\end{array}$ & Study Design & Outcome Measurement & Findings & $\begin{array}{l}\text { Method to Locate } \\
\text { Glands }\end{array}$ & Side Effects \\
\hline Narayanaswami et al. [18] & 10 & $\begin{array}{l}\text { Randomised, double } \\
\text { blind, } \\
\text { placebo-controlled } \\
\text { crossover trial. }\end{array}$ & $\begin{array}{l}\text { 1. Subjects returned monthly for three } \\
\text { evaluations after each injection. Outcome } \\
\text { measures were saliva weight and Drooling } \\
\text { Frequency and Severity Scale. } \\
\text { 2. Systematic review of literature, followed } \\
\text { by inverse variance meta-analyses using } \\
\text { random effects models. }\end{array}$ & $\begin{array}{l}\text { 1. There was no significant change in the } \\
\text { primary outcome of saliva weight one } \\
\text { month after injection in the treatment } \\
\text { period compared to placebo period. } \\
\text { 2. Secondary outcomes did not change } \\
\text { either. Meta-analysis of six studies } \\
\text { demonstrated significant benefit of } \\
\text { Botulinum toxin on functional outcomes. } \\
\text { This study did not demonstrate efficacy } \\
\text { of incobotulinum toxin A for drooling in } \\
\text { PD, but lacked precision to exclude } \\
\text { moderate benefit. Studies evaluating } \\
\text { higher doses of incobotulinum toxin A } \\
\text { into the parotid glands may be useful. }\end{array}$ & Unspecified & $\begin{array}{l}\text { Difficulty during } \\
\text { mastication and in the } \\
\text { motor control of tongue } \\
\text { Viscous saliva. }\end{array}$ \\
\hline Petracca et al. [19] & 65 & Retrospective trial & $\begin{array}{l}\text { Drooling Frequency and Severity Scale four } \\
\text { weeks after intervention }\end{array}$ & $\begin{array}{l}250 \mathrm{U} \text { of botulinum toxin } \mathrm{A} \text { and } 2500 \mathrm{U} \\
\text { of botulinum toxin B are safe and } \\
\text { effective in the treatment of sialorrhoea, } \\
\text { even in long-term follow-up. The older } \\
\text { the age, the longer the benefit duration. } \\
\text { Patients with PD showed a more } \\
\text { favourable safety-efficacy ratio than } \\
\text { patients with ALS did. }\end{array}$ & Ultrasound & $\begin{array}{l}\text { Change of saliva } \\
\text { thickness }\end{array}$ \\
\hline Sen et al. [16] & 16 & $\begin{array}{l}\text { Retrospective analysis } \\
\text { between February } \\
2009 \text { and September } \\
2013\end{array}$ & $\begin{array}{l}\text { Severity of sialorrhoea prior to treatment } \\
\text { was measured in accordance with Drooling } \\
\text { Frequency and Severity Scale (DFSS). } \\
\text { Efficacy was assessed } 4 \text { weeks after } \\
\text { injections of BoNT-A by using DFSS and } \\
\text { according to the subjective evaluation of } \\
\text { patients and/or carers (caregivers). }\end{array}$ & $\begin{array}{l}\text { Efficacy was } 100 \% \text { and mean } \\
\text { improvement in sialorrhoea was } \\
71.78 \pm 12.95 \% \text {. There was a significant } \\
\text { difference between the first and last } \\
\text { application regarding the mean duration } \\
\text { of efficacy }(17.28 \pm 9.21 \text { weeks and } \\
18.03 \pm 9.02 \text { weeks, respectively, } \\
p=0.001) \text {. Repeated BoNT-A injections } \\
\text { are safe and effective in the treatment of } \\
\text { sialorrhoea in patients with PD. }\end{array}$ & $\begin{array}{l}\text { External anatomical } \\
\text { landmarks }\end{array}$ & Not seen \\
\hline
\end{tabular}




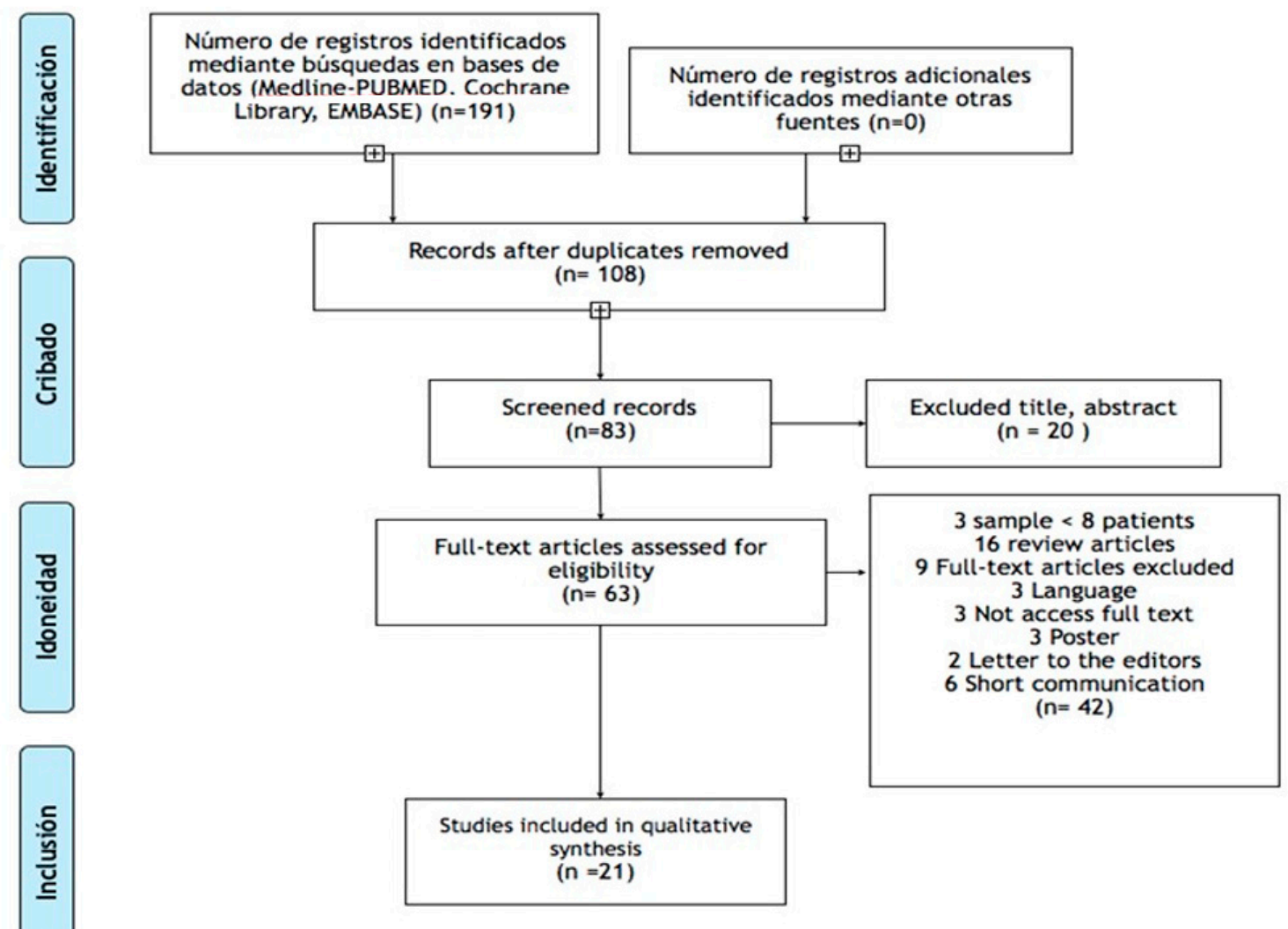

Figure 1. Flow diagram.

In therapeutics, two serotypes of botulinum toxin are commonly used: A (BoNT-A) and B (BoNT-B), although in the majority of studies the effectiveness of A is tested. On the other hand, there are major differences between $\mathrm{A}$ and $\mathrm{B}$ regarding the administered doses, accepting in most studies a 1:10 ratio, i.e., the equivalence of $10 \mathrm{U}$ of $\mathrm{A}$ with $100 \mathrm{of} \mathrm{B}$, so that a comparison between both of them can be established [30]. The dosage protocol (number of sessions, etc.) was different for each case, since no standardisation of criteria was found in the protocols.

Some authors, including Breheret et al. [17], studied the efficacy of BoNT-A, used seven different treatments combining various doses for both the parotid and submandibular glands, indicating that two ultrasound-guided injections of $15 \mathrm{mU}$ in each parotid gland and one ultrasound-guided injection of $20 \mathrm{mU}$ in each submandibular gland is the most effective dose and regimen.

However, Narayanaswami et al. [18] injected doses of $20 \mathrm{U}$ and $30 \mathrm{U}$ in the parotid and submandibular glands respectively, although no statistically significant improvement was detected.

In one study 25-40 units of BoNT-A were used in the parotid gland and 15-30 in the submandibular gland, with $40 \%$ reduction of drooling after two weeks of treatment and effectiveness within the following two months. Some years later, in 2014, these same authors conducted a similar study but with 750-2500 units of BoNT-B injected in both glands as well. A reduction of drooling between $30 \%-70 \%$ was observed after 6 weeks of treatment and $20 \%$ at week 12 .

In another publication [13] 3 groups were created and doses were injected in the parotid and submandibular glands, increasing the doses by 50, 100 and 200 units in each group. There was greater effectiveness in the latter group, with a reduction of drooling until 24 weeks.

Two other authors [14,19], compared the effectiveness of BoNT-A with respect to BoNT-B by dosing 250 units and 2500 units respectively, in both glands-i.e., the same amount because they assumed as a conversion factor the ratio 1:10. Both therapies were equally effective and safe for the control of sialorrhea, so given a choice, these Italian authors opted for B whose costs or RRP 
(recommended retail price) was much lower, at least in Italy. According to these authors, the toxin additionally obtains better results in this type of underlying condition (PD) than in others, such as ALS. In these studies, neither the anticholinergic treatment nor the medication for other pathologies were discontinued or suspended, and, in general terms, it was not specified whether they had tried other treatments for sialorrhea or whether they were using one at that time and they applied the toxin as an adjuvant, so, perhaps, the results on the effectiveness of the toxin could be masked or biased.

The method to diagnose sialorrhea is very diverse and includes the measurement of the amount of excreted saliva, subjective scales or validated questionnaires like the Non-motor Symptoms Questionnaire for PD [31], the Non-motor Symptoms Assessment Scale for PD [32], the Rabboud Oral Motor Inventory for PD [33], the Drooling Rating Scale [34], the Scales for Outcomes in PD-Autonomic [35], the Sialorrhea Clinical Scale for PD [36] or the Drooling Frequency and Severity Scale [37]. In the case of DFSS—which is the most commonly used technique for studying drooling associated with other pathologies-it was considered an effective treatment when drooling was reduced by two points on the scale [20,22-25].

In relation to the adverse effects, it should be noted that in three studies no side effects were highlighted, in two of them nothing was specified in that regard, and in the rest of cases in which an alteration occurred, this was of a mild nature, for example viscous saliva, dry mouth, difficulty in the motor control of tongue, skin reaction and aggravation of previous dysphagia. [4,7,13-16,26-29].

\section{Discussion}

Sialorrhea is a severe complication in PD patients—especially in the advanced stages—so the treatment is, therefore, considered of special importance. However, throughout the review no clear and widely supported protocol was found for the effective treatment of sialorrhea in PD patients, although it seems that the best dose of BoNT-A would range between $100 \mathrm{U}[13,14]$ and $250 \mathrm{U}[11,19]$, and equivalent doses of BoNT-B around $2500 \mathrm{U}[14,19]$ would have the same effectiveness, leaving an interval of approximately two weeks to three months between injections and using ultrasound as a guidance method, since it is safe and relatively easy to perform.

In addition, when directly comparing the doses administered in prior studies some factors, such as differences in the number of injected salivary glands and the proportion of BoNT-A injected into them influenced. Possible adverse events potentially considered and associated with BoNT-B are dry mouth, changes in saliva thickness, mild temporary dysphagia, mild weakness of mastication and diarrhoea.

The exact injection site can be located in several manners: guided by ultrasound, electromyography or palpating the gland by previously locating a series of facial anatomical landmarks. In recent publications, like the article by Breheret et al. [17], the manner to locate this site has caused controversy. The need for ultrasound is still unclear, suggesting that in the majority of cases it is possible to inject the botulinum toxin by solely palpating the parotid gland, although it is true that ultrasonography does not involve risks or adverse events.

Many studies $[3,4,7]$ have shown that with repeated injections, the time of effectiveness is prolonged, i.e., the mean duration of effectiveness increases along with the number of injections, and can even reach up to three years of effectiveness. One study proposes intervals of three months between injections, another one intervals of four months, whereas in another study the botulinum toxin is injected every two weeks. The rest acts according to the response to treatment. With regard to the duration of the effects of the treatment, it ranges from six weeks to seven months depending on the study reviewed and the follow-up period. 


\section{Limitations}

In this systematic review an assessment of the botulinum toxin in patients with Parkinson's disease was applied. The review resulted in the exclusion of studies which, perhaps, could have presented relevant data or outcomes regarding the use of botulinum toxin for other neurological conditions. The majority of studies additionally injected this toxin without long-term follow-up.

\section{Conclusions}

One of the major defects in the assessment of the effectiveness of the botulinum toxin-based treatment is the heterogeneity of data, since the criteria or diagnostic methodology for sialorrhea are not the same, so it is not possible to homogenise the resulting sample (type of toxin, parotid or submandibular gland) in terms of recovery or severity-most studies do not usually specify the interval between doses. In general, botulinum toxin is observed to be an effective option to treat sialorrhea in patients with Parkinson's disease, although studies with better designs, larger samples, dose uniformity, frequency and longer follow-up period are undoubtedly necessary to offer more significant outcomes.

Author Contributions: Conceptualization, J.A.R.-R., E.P.-F. and P.L.-J.; methodology, J.A.R.-R., E.P.-F. and P.L.-J.; software, J.A.R.-R., E.P.-F. and P.L.-J.; formal analysis, J.A.R.-R., E.P.-F. and P.L.-J.; investigation, J.A.R.-R., E.P.-F. and P.L.-J.; resources, J.A.R.-R., E.P.-F. and P.L.-J.; data curation, J.A.R.-R., E.P.-F. and P.L.-J.; writing-original draft preparation, J.A.R.-R., E.P.-F. and P.L.-J.; writing-review and editing, J.A.R.-R., E.P.-F. and P.L.-J.; visualization, J.A.R.-R., E.P.-F. and P.L.-J.; supervision, J.A.R.-R., E.P.-F. and P.L.-J.; project administration, J.A.R.-R., E.P.-F. and P.L.-J.; funding acquisition, J.A.R.-R., E.P.-F.

Conflicts of Interest: The authors declare no conflict of interest.

\section{References}

1. Connolly, B.S.; Lang, A.E. Pharmacological treatment of Parkinson disease: A review. JAMA 2014, 30, 1670-1683. [CrossRef] [PubMed]

2. Seppi, K.; Ray Chaudhuri, K.; Coelho, M.; Fox, S.H.; Katzenschlager, R.; Perez Lloret, S.; Weintraub, D.; Sampaio, C.; The collaborators of the Parkinson's Disease Update on Non-Motor Symptoms Study Group on behalf of the Movement Disorders Society Evidence-Based Medicine Committee. Update on treatments for nonmotor symptoms of Parkinson's disease-an evidence-based medicine review. Mov. Disord. 2019. [CrossRef] [PubMed]

3. Møller, E.; Karlsborg, M.; Bardow, A.; Lykkeaa, J.; Nissen, F.H.; Bakke, M. Treatment of severe drooling with botulinum toxin in amyotrophic lateral sclerosis and Parkinson's disease: Efficacy and possible mechanisms. Acta Odontol. Scand. 2011, 69, 151-157. [CrossRef] [PubMed]

4. Bruno, V.A.; Fox, S.H.; Mancini, D.; Miyasaki, J.M. Botulinum Toxin Use in Refractory Pain and Other Symptoms in Parkinsonism. Can. J. Neurol. Sci. 2016, 43, 697-702. [CrossRef] [PubMed]

5. Cardoso, F. Botulinum toxin in parkinsonism: The when, how, and which for botulinum toxin injections. Toxicon 2018, 147, 107-110. [CrossRef] [PubMed]

6. Chinnapongse, R.; Gullo, K.; Nemeth, P.; Zhang, Y.; Griggs, L. Safety and Efficacy of Botulinum Toxin Type B for Treatment of Sialorrhea in Parkinson's Disease: A Prospective Double-Blind Trial. Mov. Disord. 2012, 27, 219-226. [CrossRef] [PubMed]

7. Gómez-Caravaca, M.T.; Cáceres-Redondo, M.T.; Huertas-Fernández, I.; Vargas-González, L.; Carrillo, F.; Carballo, M.; Mir, P. The use of botulinum toxin in the treatment of sialorrhea in parkinsonian disorders. Neurol. Sci. 2015, 36, 275-279. [CrossRef] [PubMed]

8. Jost, W.H. The option of sonographic guidance in Botulinum toxin injection for drooling in Parkinson's disease. J. Neural Transm. 2016, 123, 51-55. [CrossRef] [PubMed]

9. Nicaretta, D.H.; de Rosso, A.L.Z.; Maliska, C.; Costa, M.M. Scintigraphic analysis of the parotid glands in patients with sialorrhea and Parkinson's disease. Parkinsonism Relat. Disord. 2008, 14, 338-341. [CrossRef] [PubMed] 
10. Cheng, Y.Q.; Ge, N.N.; Zhu, H.H.; Sha, Z.T.; Jiang, T.; Zhang, Y.D.; Tian, Y.Y. Dihydroergotoxine mesylate for the treatment of sialorrhea in Parkinson's disease. Parkinsonism Relat. Disord. 2018, 58, 70-73. [CrossRef] [PubMed]

11. Mazlan, M.; Rajasegaran, S.; Engkasan, J.P.; Nawawi, O.; Goh, J.K.; Freddy, S.J. A Double- Blind Randomized Controlled Trial Investigating the Most Efficacious Dose of Botulinum Toxin-A for Sialorrhea Treatment in Asian Adults with Neurological. Toxins 2015, 7, 3758-3770. [CrossRef] [PubMed]

12. Lakraj, A.A.; Moghimi, N.; Jabbari, B. Sialorrhea, anatomy, pathophysiology and treatment with emphasis on the role of botulinum toxins. Toxins 2013, 5, 1010-1031. [CrossRef] [PubMed]

13. Evangelos, A.; Michael, R.; Theodoros, A.; Vasiliki, Z.; Thomas, Z.; Ioannis, E. Volume matters, the influence of different botulinum toxin-A dilutions for sialorrhea in amyotrophic lateral sclerosis. Muscle Nerve 2013, 47, 276-278. [CrossRef] [PubMed]

14. Guidubaldi, A.; Fasano, A.; Ialongo, T.; Piano, C.; Pompili, M.; Masciana, R.; Siciliani, L.; Sabatelli, M.; Bentivoglio, A.R. Botulinum Toxin A Versus B in Sialorrhea, A Prospective, Randomized, Double-Blind, Crossover Pilot Study in Patients with Amyotrophic Lateral Sclerosis or Parkinson's Disease. Mov. Disord. 2011, 26, 313-319. [CrossRef] [PubMed]

15. Møller, E.; Daugaard, D.; Holm, O.; Winge, K.; Bardow, A.; Lykkeaa, J.; Belhage, B.; Bakke, M. Repeated treatments of drooling with botulinum toxin B in neurology. Acta Neurol. Scan. 2015, 131, 51-57. [CrossRef] [PubMed]

16. Şen, A.; Arpaci, B. Effects of repeated botulinum toxin treatment for sialorrhea in patients with Parkinson's Disease. Noro-Psikyatri. Arsivi. 2015, 52, 69-72. [CrossRef] [PubMed]

17. Breheret, R.; Bizon, A.; Jeufroy, C.; Laccourreye, L. Ultrasound-guided botulinum toxin injections for treatment of drooling. Eur. Ann. Otorhinolaryngol. Head Neck Dis. 2011, 128, 224-229. [CrossRef] [PubMed]

18. Narayanaswami, P.; Geisbush, T.; Tarulli, A.; Raynor, E.; Gautam, S.; Tarsy, D.; Gronseth, G. Drooling in Parkinson's disease: A randomized controlled trial of incobotulinum toxin A and meta-analysis of Botulinum toxins. Parkinsonism Relat. Disord. 2016, 30, 73-77. [CrossRef] [PubMed]

19. Petracca, M.; Guidubaldi, A.; Ricciardi, L.; Ialongo, T.; Del Grande, A.; Mulas, D.; Di Stasio, E.; Bentivoglio, A.R. Botulinum Toxin A and B in sialorrhea: Long-term data and literature overview. Toxicon 2015, 107, 129-140. [CrossRef] [PubMed]

20. Lagalla, G.; Millevolte, M.; Capecci, M.; Provinciali, L.; Ceravolo, M.G. Long-lasting benefits of botulinum toxin type B in Parkinson's disease-related drooling. J. Neurol. 2009, 256, 563-567. [CrossRef] [PubMed]

21. Tiigimäe-Saar, J.; Taba, P.; Tamme, T. Does Botulinum neurotoxin type A treatment for sialorrhea change oral health? Clin. Oral Investig. 2017, 21, 795-800. [CrossRef] [PubMed]

22. Svetel, M.; Vasić, M.; Dragasević, N.; Pekmezović, T.; Petrović, I.; Kostić, V. Botulinum toxin in the treatment of sialorrhea. Vojnosanit. Pregl. 2009, 66, 9-12. [CrossRef] [PubMed]

23. Lagalla, G.; Millevolte, M.; Capecci, M.; Provinciali, L.; Ceravolo, M.G. Botulinum toxin type A for drooling in Parkinson's disease: A double-blind, randomized, placebo-controlled study. Mov. Disord. 2006, 21, 704-707. [CrossRef] [PubMed]

24. Nóbrega, A.C.; Rodrigues, B.; Torres, A.C.; Enzo, A.; Melo, A. Does botulinum toxin decrease frequency and severity of sialorrhea in Parkinson's disease? J. Neurol. Sci. 2007, 253, 85-87. [CrossRef] [PubMed]

25. Ondo, W.G.; Hunter, C.; Moore, W. A double-blind placebo-controlled trial of botulinum toxin B for sialorrhea in Parkinson's disease. Neurology 2004, 62, 37-40. [CrossRef] [PubMed]

26. Mancini, F.; Zangaglia, R.; Cristina, S.; Sommaruga, M.G.; Martignoni, E.; Nappi, G.; Pacchetti, C. Double-blind, placebo-controlled study to evaluate the efficacy and safety of botulinum toxin type A in the treatment of drooling in parkinsonism. Mov. Disord. 2003, 18, 685-688. [CrossRef] [PubMed]

27. Friedman, A.; Potulska, A. Quantitative assessment of parkinsonian sialorrhea and results of treatment with botulinum toxin. Parkinsonism Relat. Disord. 2001, 7, 329-332. [CrossRef]

28. Pal, P.K.; Calne, D.B.; Calne, S.; Tsui, J.K. Botulinum toxin A as treatment for drooling saliva in PD. Neurology 2000, 54, 244-247. [CrossRef] [PubMed]

29. Santamato, A. Botulinum toxin type A in the treatment of sialorrhea in Parkinson's disease. J. Am. Geriatr. Soc. 2008, 56, 765-767. [CrossRef] [PubMed]

30. Rosales, R.L.; Bigalke, H.; Dressler, D. Pharmacology of botulinum toxin: Differences between type A preparations. Eur. J. Neurol. 2006, 13 (Suppl. S1), 2-10. [PubMed] 
31. Chauhuri, K.R.; Martínez-Marín, P.; Brown, R.G.; Schapira, A.H.; Strocchi, F.; Sethi, K.; Odin, P.; Brown, R.G.; Koller, W.; Barone, P.; et al. International multicenter pilot study of the first comprehensive self-completed nonmotor symptoms questionnaire for Parkinson's disease: The NM-SQuest study. Mov. Disord. 2006, 21, 916-923. [CrossRef] [PubMed]

32. Chauhuri, K.R.; Martínez-Marín, P.; Brown, R.G.; Sethi, K.; Strocchi, F.; Odin, P. The metric properties of a novel non-motor symptoms scale for Parkinson's disease: Results from an international pilot study. Mov. Disord. 2007, 22, 1901-1911. [CrossRef] [PubMed]

33. Kalf, J.G.; Borm, G.F.; de Swart, B.J.; Bloem, B.R.; Zwarts, M.J.; Munneke, M. Reproducibility and validity of patient-rated assessment of speech, swallowing, and saliva control in Parkinson's disease. Arch. Phys. Med. Rehabil. 2011, 92, 1152-1158. [CrossRef] [PubMed]

34. Marks, L.; Turner, K.; O'Sullivan, J.; Deighton, B.; Lees, A. Drooling in Parkinson's disease: A novel speech and language therapy intervention. Int. J. Lang. Commun. Disord. 2001, 36, 282-287. [CrossRef] [PubMed]

35. Visser, M.; Marinus, J.; Stiggellbout, A.M.; van Hilten, J.J. Assessment of autonomic dysfunction in Parkinson's disease: The SCOPA-AUT. Mov. Disord. 2004, 19, 1306-1312. [CrossRef] [PubMed]

36. Pérez-Lloret, S.; Pirán Arce, G.; Rossi, M.; Caivano Nemet, M.L.; Salsamendi, P.; Merello, M. Validation of a new scale for the evaluation of sialorrhea in patients with Parkinson's disease. Mov. Disord. 2007, 22, 107-111.

37. Thomas-Stonell, N.; Grrenberg, J. Three treatment approaches and clinical factors in the reduction of drooling. Dysphagia 1988, 3, 73-78. [CrossRef] [PubMed]

(C) 2019 by the authors. Licensee MDPI, Basel, Switzerland. This article is an open access article distributed under the terms and conditions of the Creative Commons Attribution (CC BY) license (http://creativecommons.org/licenses/by/4.0/). 